LILIYA MORSKA (Ternopil, Ukraine)

\title{
TEACHING INTERCULTURAL COMMUNICATIVE COMPETENCE: THEORETICAL BACKGROUND
}

Стаття присвячена дослідженню теоретичних основ сутності міжкультурної комунікативної компетентності та розробці практичних засад для розробки відповідної дидактичної моделі для реалізації методики формування цієї компетентності. Автор припускає, що ті, хто вивчають анелійську мову, в майбутньому будуть більше спілкуватися із собі подібними, ніж із носіями мови. Саме тому у статті наголошується на перенесенні акценту у вивченні англійської мови для надання студентам можливості висловити свої думки відповідно до культурних цінностей не лише носіям мови, але й представникам інших культур. Відповідно, питання міжкультурної комунікації стає невід'ємним у вивченні англійської мови, особливо студентів, що вивчають іноземну мову за професійним спрямуванням.

Ключові слова: міжкультурна комунікативна компетенція, міжкультурна комунікація, взаємодія, компетенція, навчальні стратегії, культура

Global considerations impact everyday business decisions for companies large and small. Where should we produce, market, and sell our products and services? For most, it is a global market to consider. One only needs to examine the current and projected growth of international trade to clearly see the impact on our future. Corporations are aware that to be successful in tomorrow's marketplace requires employees to be competent in communicating with those from other cultures. In the past, most international managers relied on general cultural guidelines for conducting intercultural negotiations. However, the increase in global trade transactions has resulted in integrated cultural exchanges, new cultural partnerships, and unique cultural interactions, making old, superficial generalities less accurate.

In today's world of global village, living with differences both at home and abroad is becoming more important. Differences such as values, attitudes, culture, ethnicity, social practices, political beliefs, sexuality and religion clearly direct people all around the world who embarked various meanings to their surroundings according to their individual attitudes that must be fully respected and integrated into life (Tesoriero 2006). In recent years, many scholars have completed various studies to deal with these differences, and as a result of these studies one particular and important aspect of working with difference is conceptualized as 'intercultural communication competence' (ICC).

Intercultural communication competence grew out of the interpersonal communication competency research. The contextual distinctiveness of the intercultural interaction is a unique communication competency issue. It is possible that an individual may be highly competent in communicating with others in his or her own culture but not competent when interacting with others who are culturally different.

The goal of teaching a foreign language has always been the issue of hot debates in language teaching methodology. With emergence of Competence-based Approach the idea of teaching communicative competence became quite persuasive in this respect. Though, it can often be heard in teaching circles that language is culture, so should we teach the language as part of culture or we could get off with pronunciation, grammar and vocabulary fit into four speech skills? If the first option is to be tackled (as has been approved of in recent perspective investigations) then what can be called «communicative competence» (CC) and what role is played by culture in it?

The communicative approach considers target language-based communicative competence essential for foreign language learners to participate fully in the target language culture. As such, the target language culture and its inhabitants, the native speakers, are elements crucial to the success of the teaching model. Learners are not only expected to acquire accurate forms of the target language, but also to learn how to use these forms in given social situations in the target language setting to convey appropriate, coherent, and strategically effective meanings for the native speaker. Thus, learning a foreign language becomes a kind of enculturation, where one acquires new cultural frames of reference and a new world view, reflecting those of target language culture and its speakers. 
However, despite this increased focus on sociocultural elements, writers have been critical of the way that communicative language teaching has tended to ignore the sociocultural dimension of these proposed models of communicative competence, and that it has instead assumed a certain universality in the way in which speech functions are used and interpreted. As early as 1974, Paulston pointed out that the communicative approach was tending to concentrate mainly on referential meaning while ignoring the social meaning of words and phrases. Buttjes (1991) suggests that communicative language teaching excluded the learners' cultural background and failed to see the acquisition of communicative competence as a process of cultural adaptation. Instead, teachers used role-plays and video observations to train their learners in the use of pragmatic strategies and appropriate speech functions in authentic situations. Roberts, Byram, Barro, Jordan and Street (2001) conclude that, while communicative language methodology has done much to highlight the social contexts of language use, it: «has come to be interpreted somewhat narrowly and prescriptively, as appropriate language use rather than competence in the social and cultural practices of a community of which language is a part.» (Roberts et. al., 2001:26)

However, it appears that the absence of overt attention to the learners' cultural background in the communicative methodologies of the 1970's and 1980's was motivated by a more complex set of reasons than simply a narrow interpretation of what communicative competence involved. Firstly, the lack of a cultural component during that time (and, to some extent, still today) reflects a common belief that English should be considered a global language or Lingua franca. Of course, this could only be achieved if English was seen as «a neutral vehicle of communication, an empty structural system that does not carry with it cultural, political and ideological baggage» (Anderson, 2003: 81). Therefore, it was necessary to try and disassociate English from its cultural heritage. The argument at the time seemed to imply that as students were going to be using English in contexts other than in English speaking cultures, then it was unnecessary to burden them with information about these cultures. Commentators such as Gray (2002) have pointed out how the English language teaching industry adopted this trend in the 1980's by moving the location of English language textbooks from Britain and the United States to international settings. Similarly, instead of dealing with issues of relevance to the learners' target or home cultures, the content of textbooks focused more on 'bland' topics such as travel and the future and thereby avoided any risk of insulting buyers from different cultural backgrounds.

The other reason for the decline of the cultural component in language teaching during this period also had a political background. In the late 1980's, writers such as Brumfit (1985), Phillipson (1992) and Prodromou (1988) were influential in making English language educators question the consequences and impact of their profession. Phillipson's work caused many to consider whether English language teaching represented some kind of new, more subtle form of linguistic and cultural imperialism and whether their methodologies and materials had more to do with assimilation of learners than with their empowerment. As a result of this preoccupation with avoiding the imposition of their cultural values and principles on their students, Pulverness suggests that English teachers chose to avoid cultural content completely: «At a time when Britain no longer occupies a dominant political position in the world, it is perhaps reassuring for teachers to feel that they are permitted to treat English purely in terms of a language system, uncomplicated by any cultural sub-text. Cultural knowledge in EFL classrooms ... has remained largely peripheral to language learning, acquired by students incidentally, but rarely focused on for its own sake.» (1995:25)

Answering the above mentioned and other questions including the query of what dimensions are applied in understanding the word "culture», what kind of culture is practiced in the English-speaking world, it is essential to take a closer look at the perception of CC. It has been generally acknowledged that CC can be viewed as communication behaviour in achieving goals by exhibiting this behaviour in an appropriate way in a certain situation (Spitzberg and Cupach, 1984). To be able to demonstrate such behaviour a communicatively competent individual, according to Canale and Swain's influential model of communicative competence (1983), should possess grammatical, sociolinguistic, discourse and strategic competencies which, in our view, refer 
to integration of Chomsky's concept of linguistic competence (grammatical competence) within culture-specific social context (sociolinguistic competence) and the ability to cope in an authentic communicative situation (strategic competence) avoiding interaction misunderstandings by the extended use of the language in culturally and socially varied surrounding (discourse competence).

The given above components of communicative competence should be viewed from the perspective of reality. Considering the first issue of grammatical competence, it is important to analyze what kind of language system should be acquired by an English language learner in order to enable him/her to use it in a certain culture-specific social context. There are at least two options in this respect: 1) the language of BBC (which casts some doubts on the possible chances to use this type of language in other than BBC studio surrounding social contexts); 2) the language commonly heard in ordinary surroundings (in the streets, supermarkets, offices, plants and factories, to name but a few). To exacerbate the issue, it shouldn't be forgotten to be mentioned that there is a huge variety of dialects spoken by people in English speaking countries (not to mention the discrepancies in Englishes of those countries) (Alptekin, 2002: 48). So the question then arises like this: what kind or type of culture-specific social context should be chosen to be included in the curriculum for English language learners?

One of the principal outcomes of the decline in cultural content in communicative language teaching was that it moved the focus of the language classroom from preparing learners to read in the foreign language to being tourists in the foreign country. The content of many communicative syllabuses involved helping learners to buy bus tickets, ask the way and order food in the target language. This was criticized by many as a superficial approach which lead to the trivialisation of language learning and a lack of motivation among students. Pennycock sees it as being responsible for creating what he describes as «the empty babble of the communicative language class» (1994: 311). Bredella and Christ (1995) suggest that the problem with this approach was that learners were encouraged to believe that interlocutors from different cultures would automatically mean and understand the same thing when engaged in conversation together. There- fore, there was no need for learners to ask others what they meant by their utterances and, and as a result, to find out more about the different worldview of their partners. In other words, no 'negotiation of meaning' ever took place.

Furthermore, we are concerned with a quest of what should be meant by «an authentic communicative situation» in which a learner has to deal using English, depending on his/her communicative behaviour goals. In this view it is significant to highlight the fact that the term «authentic communicative situation» is now perceived as the one where English is used as the means of international communication, since social and economic globalization has necessitated the use of international English spoken in the «global village». It can be explained by a mere example of two people doing business in Germany though being an Italian and a Japanese by nationality but still using English at work. Then there emerges another issue which needs clear analysis in terms of whose culture should be primary to make these two people communicatively competent (following the Canale and Swain's model): British or American or Canadian or Australian or German or Japanese or Italian? Or maybe International?

Another question arises concerning the definition of the "native speaker» whose model of communicative competence should be acquired by foreign language learners according to Canale and Swain's model of CC. Kramsch (1998), concentrates more on the sociological and political consequences of the importance which is attributed to the native speaker and looks at how membership of the group 'native speaker' has been awarded - by birth, by education, or by membership to the social community - and analyses the weaknesses which each of these involve. According to the author, being born in the country does not make one automatically a native speaker, as many people who are born into a society do not automatically come to know and speak the standard dialect of that society, for example Glaswegians in Scotland or children born of Chinese immigrants in the United States. She also rejects the theory that being educated in a language is sufficient to achieve native speaker status, as the membership of this group involves much more than fluency and full communicative competence in the language. Instead, "one must be recognized as a native speaker by the relevant speech 
community» (1998: 22). Kramsch therefore concludes that the term native speaker is more social and political than linguistic and she suggests that the realities such as increased use of English as a lingua franca, the multicultural nature of modern societies and the increasing importance given to nonstandard English dialects has rendered the term an «outdated myth» (1998: 23).

As English is on the way to spread as an international language, the number of its users is set to grow, and soon will far exceed the number of native speakers of English. Thus, we presume that the learners of English will be more likely to use it to interact more with the same type of people rather than the native speakers. Therefore, we are witnessing the shifts in the goal of learning English as to enable learners to communicate their ideas and culture with not only native English speakers but also those of other cultures. Consequently, the question of intercultural communication is inevitably indispensable in English language learning as far as students' communicative competence development is of primary concern.

The processes of national and international integration have predetermined modernization tendencies of Ukrainian foreign language education. Today a foreign language is a means of world comprehension being the tool of recognition of the values of other nations, of cultural uniqueness discovery. Thus, it has become necessary to build a personality that doesn't only speak a foreign language, but is ready to participate in the global society, to understand it, to respect the other foreign cultural identities. This has led to shifting the emphasis which has been traditionally accepted for the past decades from the importance of formation of foreign communicative competence to the necessity of formation of foreign intercultural communicative competence.

The desire to understand other cultures and their representatives has been urgent for as much time as the cultural and ethnic diversity has been in existence, that's why the notion of intercultural communication is still being discussed greatly in scientific and methodical papers.

The majority of the scientists now consider that the case for intercultural communication (interaction) is valid as long as people represent different cultures and are aware of everything that doesn't belong to their culture recognizing it as something «strange». The relationships then become intercultural meaning that people don't act according to their national traditions, customs, behaviour patterns, but try to get familiar with the "strange» behaviour rules and norms of everyday communication. Moreover, here both common and different peculiarities come up, so that people can distinguish them and accept thoroughly (Кирабаев :15).

In summary, in this section it has been shown how social and political factors such as increased migration and the growth of transnational communication (Kramer, 2000) as well as a questioning of what the goals of the language learner should be have led to criticism of the communicative approach to foreign language teaching and its inherent 'native speaker as standard' model. As an alternative, recent approaches have proposed the 'intercultural speaker' as an alternative goal for models of foreign language learning. Byram and Fleming describe such a learner in the following way: «lt is the learner who is aware of their own identities and cultures, and of how they are perceived by others, and who also has an understanding of the identities and cultures of those with whom they are interacting. This intercultural speaker is able to establish a relationship between their own and other cultures, to mediate and explain difference - and ultimately to accept that difference and see the common humanity beneath it.» (Byram and Fleming 1998: 8) However, it has been questioned whether such an approach should not lead to an avoidance of materials which focus on the target culture itself. Studying target cultures does not imply that the norms, values and pragma-linguistic rules of this culture have to be imposed on the learner. Nevertheless, learners have a right to be exposed to the foreign culture in order to be made aware of alternative worldviews and to be given the option of 'taking on' aspects of this culture if it is in their personal interests.

To summarize the stated above ideas, we have to conclude that the English language became the medium of intercultural communication, and it caused the emergence of new approaches to its learning in educational establishments, particularly in school. Having investigated the possible solution to such an urgent problem the following ideas can be expressed:

1) Having analyzed the notion of intercultural communication and its components it is possible to say that they are nationally-specific components and require understanding in 
situations of intercultural communication, so it is necessary to familiarize students with them, train them to understand their nature, thus developing their ability to communicate on intercultural level. On this basis we can say that the advantage of learning language and culture in relationship on the level with traditional one is manifesting in the development of skills to communicate with native speakers in real life situations.

2) Interacting with people from other cultures we can face barriers in perception (preconceptions, stereotypes, dimensions of collectivism versus individualism, history and experience, roles by gender or social class, values, customs, uncertainty, ethnocentrism) non-verbal (tone and loudness of voice, facial expression, posture, gestures, eye contact, chronemics, haptics, space in communication, kinesics and proxemics) and verbal processes (competency in writing and speaking a language, idioms, slang, jargon, figurative expressions, exaggeration/understatement). To overcome difficulties in intercultural communication, it is necessary to follow such general guidelines: have a positive attitude about communication. Defensiveness interferes with communication; speak slowly and clearly; avoid assuming you've understood what's been said; practice reflective listening to check your own understanding; and use open-ended questions to check other people's understanding; avoid using slang and idioms, choosing words that will convey only the most specific denotative meaning; listen carefully and, if in doubt, ask for confirmation of understanding (particularly important if local accents and pronunciation are a problem); watch for any changes in body language; investigate their culture's perception of your culture by reading literature about your culture through their eyes before entering into communication with them; be patient.

3) The principles of intercultural communicative competence are interconnected and constitute the basis for development of methodology of intercultural English-speaking strategies formation. The aim of intercultural strategies is to teach students to communicate with the English-speaking native speakers, taking into account personal needs and requirements of modern society, and the process of their formation consists of four levels. To achieve this goal in formation of intercultural English-speaking communicative competence one has to follow the following strategies: the use of lectures to explore foreign cultures, com- munication with native speakers, listening to audio recordings interviews, video-record interviews and reading of authentic texts. These intercultural communicative strategies, which enable to depart from the standard pattern of the English language teaching, will make training more effective and help to succeed in intercultural communication.

4) On the basis of critical review of domestic and foreign researches as well as a thorough analysis of the practical material, we can say that the choice of learning content, organization and presentation of training materials should be accomplished taking into account students' interests which appear in the process of study.

5) It has been found that the most appropriate and most effective activities for teaching intercultural communication in higher forms are cultural assimilations, cultural capsules, mini-dramas, role-plays, social and cultural tasks, the use of media, training, comparative and project technology. We have determined that for the formation of students' intercultural communicative competence it is necessary to choose such means of assessment as tests, portfolios, observation, interviews, summary of material analysis in diaries, report of the foreign/own culture monitoring means. They will help quickly and objectively identify the level of knowledge and formation skills of readiness for the intercultural interaction. The carried out investigation suggests that the developed methodology of intercultural English-speaking communicative strategies formation in students is effective. On the basis of our research guidelines for intercultural communication training have been formulated.

6) We consider it appropriate to emphasize the fact that intercultural communication training promotes expansion of worldviews, strengthening the motivation for language learning, developing intercultural communication skills, content of foreign language studies, optimization and updating traditional teaching languages with information and methodology and providing training to use foreign language in any environment.

7) The social dimension of this theoretical explication delineates the interactional aspect of the communication process. Knowledge involves knowing the personal, relational, and cultural standards of competences and the skills are depicted in the behavior of the communicator. Inability to perform the "standards" of what is considered competent results in perception of incompetent communication. 
8) To enhance the potential of foreign language lessons in terms of intercultural communicative competence development it is significant to encourage students into participation in the network-based international language learning projects accomplished in collaboration with the students from a variety of cultures using the same foreign language.

\section{References}

Alptekin, C. (2002). Towards intercultural communicative competence in ELT. ELT Journal, 56 (1), 46-54.

Anderson, C. (2003). Phillipson's children. Language and intercultural communication, 3(1), 81-94.

Bredella, L. and Christ, H. (1995). «Didaktik des Fremdverstehens - Ein Forschungsprogramm im Rahmen der Graduiertenfoerdungen. Aglistik, 5 (2), 3-16.

Brumfit, C. (1997). British Studies: an educational perspective. In: S. Bassnett (Ed.), Studying British Cultures. An Introduction (pp. 39-53). London: Routledge.

Buttjes, D. (1990). Culture in German foreign language teaching: making use of an ambiguous past. In D. Buttjes and M. Byram (Eds.), Mediating languages and cultures. Clevedon (pp. 3-16). Clevedon: Multilingual Matters.

Byram, M. and Fleming (Eds.) (1998). Language learning in intercultural perspective. Cambridge: Cambridge University Press.

Canale, M. and Swain, M. (1980). Theoretical bases of communicative approaches to second language teaching and testing. Applied Linguistics, 1: 1-47.

Gray, J. (2002). The global coursebook in English language teaching. In D. Block and D. Cameron (Eds.), Globalization \& language teaching (pp. 151-167). London: Routledge.
Gray, R. and Stockwell, G. (1998). Using computer mediated communication for language and culture acquisition. On-CALL 12 (3), 10pp. Retrieved 17 August, 2003: http://www.cltr.uq.edu. au/oncall/gray123.html

Kramer, J. (2000). Area studies. In M. Byram (Ed.), Routledge encyclopaedia oflanguage teaching and learning. (pp. 41-48). London: Routledge.

Kramsch, C. (1998). The privilege of the intercultural speaker. In M. Byram and M.Fleming (Eds.) Language learning in intercultural perspective (pp. 16-31). Cambridge: Cambridge University Press.

Paulston, C.B. (1974). Implications of language learning theory for language planning: Concerns in bilingual education. Papers in Applied Linguistics: Bilingual Education Series 1. Arlington, Va: Centre for Applied Linguistics.

Pennycock, A. (1994). The cultural practice of English as an international language. London: Longman.

Phillipson, R. (1992). Linguistic Imperialism. Oxford: Oxford University Press.

Prodromou, L. (1988). English as cultural action. ELT Journal, 42 (2), 73-83.

Pulverness, A. (1995). Cultural studies, British studies and EFL. Modern English Teacher, 4 (2).

Roberts, C., Byram, M., Barro, A., Jordan, S. and Street, B. (2001). Language learners as ethnographers. Clevedon: Multilingual Matters.

Spitzberg, Brian H., Cupach, (1984). William R. Interpersonal communication competence. -$247 \mathrm{p}$.

Tesoriero,F. (2006). 'Personal Growth Towards Intercultural Competence Through an International Field Education Programme'. Australian Social Work, 59(2):126-140.

Kirabayev N. (2005). Globalizatsiya I multiculturalism. (Кирабаев Н.C. Глобализация и мультикультурализм. - М.: Изд-во РУДН. 332 c.).

\section{TEACHING INTERCULTURAL COMMUNICATIVE COMPETENCE: THEORETICAL BACKGROUND}

\section{Liliya Morska}

Department of English Philology, Ternopil Volodymyr Hnatiuk National Pedagogical University, Ternopil, Ukraine.

\section{Abstract}

Background. The goal of teaching a foreign language has always been the issue of debates in language teaching methodology. With emergence of Competence-based Approach the idea of teaching communicative competence became quite persuasive in this respect. Though, it can often be heard in teaching circles that 
language is culture and we should teach the language as part of culture. Therefore, witnessing the shifts in the goal of learning English as to enable learners to communicate their ideas and culture with not only native English speakers but also those of other cultures, the question of intercultural communication is inevitably indispensable in English language learning as far as students' communicative competence development is of primary concern.

Purpose. The purpose of the paper is to analyze the essential issues of the intercultural communicative competence structure and to define theoretical background for developing the didactic model of teaching this competence.

Discussion. The article discusses theoretical background of pragmatic aspects of teaching intercultural communicative competence to Ukrainian speaking students in ESP educational surrounding. The author presumes that the learners of English will be more likely to use the language for interaction with non-natives rather than the native speakers. A noteworthy fact is that intercultural communication training promotes expansion of worldviews, strengthens motivation for language learning, enhances intercultural communication skills, improves content of foreign language education etc. To enhance the potential of foreign language classes in terms of developing intercultural communicative competence, it is significant to encourage students into participation in the network-based international language learning projects aimed at developing collaboration with the students from a variety of cultures using the same foreign language.

Results. It has been found out that the most effective activities for teaching intercultural communication are cultural assimilations, cultural capsules, mini-dramas, role-plays, social and cultural tasks, use of media, training, comparative and project technology. The assessment tools include tests, portfolios, observation, interviews, diaries, reports etc. They will help objectively identify the level of knowledge and skills as well as readiness for the intercultural interaction. Perspective for further studies is seen in the development of the model of teaching this competence to ESP students. The system of exercises to correlate with the model is to be developed as well.

Key words: intercultural communicative competence, intercultural communication, interaction, competence, learning strategies, culture

\section{Vitae}

Liliya Morska. Dr.Sc. in Pedagogy, Professor, Head of Department of English Philology in Ternopil Volodymyr Hnatiuk National Pedagogical University (Ternopil, Ukraine). Her research areas include Germanic studies, methods of teaching English as a second language, second language acquisition, teaching ESP.

Correspondence: liliya.morska@gmail.com 